\title{
Pediatrik Yoğun Bakımdan Taburculuk Sonrası Görülen Post-Travmatik Stres Bozukluğu ve Azaltılmasında Hemşirenin Rolü
}

\section{Duygu SÖNMEZ DÜZKAYA $^{\mathrm{a}}$}

\section{Suzan YILDIZ ${ }^{b}$}

${ }^{a}$ Ístanbul Tip Fakültesi Hemşirelik Hizmetleri Müdürlüğü

${ }^{\boldsymbol{b}}$ Istanbul Üniversitesi Florence Nightingale Hemşirelik Fakültesi Çocuk Sağlığl ve Hastalıkları Hemşireliği Anabilim Dalı Tel: 02124400000/27012 e.posta:suzyil@istanbul.edu

Yazışma Adresi/ Correspondence

Duygu Sönmez Düzkaya İstanbul Üniversitesi İstanbul Tıp Fakültesi, Hemşirelik Hizmetleri Müdürlüğü Dekanlık Binası Kat:2 Fatih, Istanbul, Türkiye Tel: $+902124142000-31458$ e.posta:dygsnmz@hotmail.com

Geliş Tarihi/Received 04.06.2014

Kabul Tarihi/Accepted 22.06.2014

HSP 2014;1(1):47-57

\section{Posttraumatic Stress Disorder After Discharge in Pediatric Intensive Care Unit}

\section{Özet}

Post travmatik stres bozukluğu (PTSB) travma sonrası ortaya çıkan, çocuk veya ailenin travmatik olayı kötü rüyalar, geçmişe dönüş, halisünasyonlar yoluyla yeniden deneyimlemesi; travmayı anımsatan olaylardan, duygulardan, aktivitelerden, konuşmalardan, mekanlardan ve insanlardan kaçınması ve aşırı uyarılma davranışı sergilemesiyle karakterize, bu semptomların en az 1 ay boyunca devam etmesi ile seyreden ciddi bir mental bozukluktur. Yoğun bakım gibi yaşamın tehdit altında olduğunu gösteren bir ünitede bulunmak hem çocuk hem de aile için kriz yaratan bir durumdur. Bu üniteden taburcu olduktan sonra çocukta ve ailede hatırlamak istemeyecekleri anıların hatırlanması ile PTSB ortaya çıkmaktadır. Bu nedenle taburculuk öncesi PTSB'nun erken tanımlanması ve hastanede uygun hemşirelik girişimlerinin uygulanması semptomların azaltılmasında önemlidir.

Anahtar kelimeler: Hemşirelik, posttravmatik stres bozukluğu, pediatrik yoğun bakım, taburculuk,

\begin{abstract}
Post traumatic stress disorder (PTSD) a mental disorder that causes after trauma occurring, the patient or family's traumatic event, bad dreams, flashbacks, hallucinations through again to experience trauma reminiscent of events, feelings, activities, conversations, places, and people avoidance and hyperarousal behavior, merchandising, characterized by the to continue for at least 1 month of symptoms. Indicates that life is under threat, such as intensive care units are in a crisis for both the child and family is a situation that creates. After being discharged from this unit as well as the child in the family will want to remember to remember memories with PTSD arises. Therefore, in the hospital prior to discharge ptsb'n early identification and implementation of appropriate nursing interventions is essential in reducing symptoms.
\end{abstract}

Key words: Discharge, nursing, posttraumatic stress disorder, pediatric intensive care

\section{Giriş}


Pediatrik yoğun bakım ünitesi (PYBÜ) ciddi fiziksel yaralanma veya hastalık nedeniyle yoğun bakım izlemi gereken çocukların bulunduğu birimlerdir. ${ }^{1} \mathrm{Bu}$ ünitelerde bulunan ve stabil olmayan çocuklar genel olarak entübasyon, aspirasyon, yara bakımı, katater, dren uygulaması ve bakımı gibi tedavilerle veya medikal durumlarla ilgili olarak bir çok travmatik olaylara maruz kalırlar. ${ }^{2}$ Bu travmatik olaylarla birlikte ortamın karışık, gürültülü, dağınık olması, hastalığın ciddiyeti ve duygusal-fiziksel kontrol kaybı gibi nedenlerle hassaslaşan çocuklar psikolojik, fizyolojik ve sosyal düzeyde yoğun stres yaşarlar. ${ }^{3,4}$

Travma bireyin yaşamının tehdit altında olduğu ya da başkasının yaşadığı travmatik olaya tanık olma durumudur ve birey üzerinde birçok etkisi görülmektedir. Ciddi mental bozukluklara yol açan travmanın birey üzerinde oluşturduğu tabloya post-travmatik stres bozukluğu (PTSB) denir. Ruhsal Bozuklukların Tanısal ve Sayımsal El Kitabı (Diagnostic and Statistical Manual of Mental Disorders-DSM IV) PTSB kriteri olarak üç semptom tanımlamıştır. Bunlar;

- İlk kriter, hasta veya ailenin travmatik olayı kötü rüyalar, geçmişin hatırlanması, halisünasyonlar yoluyla yeniden deneyimlemesi,

- İkinci kriter, hastaların travmayı hatırlatıcı duygulardan, aktivitelerden, konuşmalardan, mekanlardan ve insanlardan kaçınması,

- Üçüncü kriter, hastaların aşırı uyarılma davranışı sergilemesi; hastalar uykuya dalmakta zorlanır, irritabilite, kızgınlık, konsantrasyon güçlüğü yaşarlar.

PTSB tanısı bu semptomların en az 1 ay boyunca devam etmesi ile konur. ${ }^{1,5,6}$

Post travmatik stres bozukluğunun erişkin hastalarda prevelansı $\% 6,8^{7}$ adölesanlarda \%3,9 olarak bildirilmiştir. ${ }^{8}$ Erişkin hastalar ile yapılan çalışmada; yoğun bakım deneyiminden üç ay sonra hastaların \%14'ünde PTSB belirtileri görüldüğü bildirilmiştir. ${ }^{9}$ Zink ve ark. ${ }^{10}$ (2003)'nın 7-15 yaş arası motorlu araç kazası geçiren çocuklar ile yaptıkları çalışmada ise, çocukların \%22'sinde PTSB görüldüğü bildirilmiştir. Ülkemizde PYBÜ’den taburculuk sonrası PTSB tanısı ile ilgili yapılmış çalışma örneklerine rastlanamamıştır.

Çocuklar genellikle kaza sonucu yaralanma, akut hastalıklar, nörolojik durumun bozulması, respiratuar distres veya post-operatif bakım nedeniyle PYBÜ kabul edilirler. ${ }^{11}$ PYBÜ'de yatan çocuklar ve aileleri diğer servislerde yatan çocuklara göre daha fazla travmatik olaya maruz kalmaları nedeni ile PTSB açısından daha fazla risk altındadır. ${ }^{1,3,11}$ Yoğun bakıma kabul edilen çocuklarda PTSB için risk faktörleri arasında; aileden ayrılmak, uzun süre yoğun bakımda yatmak, uzun süre mekanik ventilasyon tedavisi almak, derin sedasyonda olmak, invazif uygulamalar (aspirasyon, beslenme sondaları, intravenöz 
girişimler, üriner sistem sondaları vb), uyku örüntüsünün bozulması, hareketsizlik, gürültülü ve ışıklı ortamda bulunma sayılabilir. ${ }^{12,13}$

İlaç ve psikoterapi PTSB'nun tedavisinde kullanılan yaygın yöntemlerdir. İlaç tedavisinde antidepresanlar, benzodiazepinler ve betablokerler gibi ilaçlar psikoterapide ise "Destekleyici Psikoterapi” ve "Davranışçı Psikoterapi” yöntemleri kullanılabilmektedir.

\section{Pediatrik Yoğun Bakım Ünitesinde Çocukların Durumu}

Günümüzde çocukluk çağı hastalıklarının fizyolojik boyutları dışında psikolojik sonuçlarının giderek artması tıp dünyasının dikkatini çekmektedir. Ancak çocuklarda PYBÜ’ne kabul ciddi ve hayatı tehdit edici bir durum olmasına rağmen, bu durumun çocuklar üzerinde yarattığ psikopatolojik değişikliklerle ilgili yapılmış çok az çalışma vardır. ${ }^{3,6}$

Erişkinler ile yapılan çalışmaları gözden geçiren Griffiths ve $\operatorname{ark}^{14}$ (2007) 30 araştırmayı değerlendirerek yoğun bakımdan çıkan hastalarda görülen PTSB oranının \% 0- 64 arasında olduğunu bulmuşlardır. Çocuklarda yapılan çalışmalar incelendiğinde; Bronner ve $\operatorname{ark}^{15}$ (2008b)'nın yaptıkları çalışmaya katılan sekiz yaşından büyük her üç çocuktan biri PYBÜ’den taburcu olduktan üç ay sonra PTSB semptomları göstermiştir. Menengial sepsis nedeniyle pediatrik yoğun bakım ünitesine alınan 2-15 yaş arası çocuklarda yapılan bir araştırmada hastaneden taburcu olduktan 3-12 ay sonra ortaya çıkan PTSB prevelansının çocuklarda \%10, annelerde \%48 olduğu bulunmuştur. Kontrol grubu olmayan araştırmada bu sonucun yoğun bakımda yatmış olmaktan mı? ya da menengial sepsis ile ilişkili olmasından mı? kaynaklandığı açığa çıkarılamamıştır. ${ }^{16}$ Schreier ve $\operatorname{ark}^{17}$ (2004)'nın PYBÜ' de yatan 83 çocuk ile yaptıkları araştırmada, çocukların \%69'unda hafif düzeyde PTSB semptomları görülürken, \%57'sinde bir ay sonra \%59'unda 6 ay sonra ve \%38'inde 18 ay sonra PTSB semptomları görülmüştür. Rees ve ark $^{3}$ (2004)'nın 35 PYBÜ'de ve 33 genel çocuk servisinde yatan çocuk ve aileleri ile yaptığı çalışmada ise, PYBÜ'den taburcu olan çocukların \%21'inde PTSB sendromu görülürken, diğer ünitelerden taburcu olan çocukların hiçbirinde görülmemiştir (Tablo 1).

Erişkin hastaların yoğun bakım ünitesine alınmasının post-travmatik stres bozukluğu sendromunu tetiklediği bilinmektedir. Aynı durum çocuklar için de geçerlidir. Araştırma bulguları ile PYBÜ'de bulunmanın diğer servislerde bulunmaya oranla daha stresli olduğu ifade edilmiştir. Aile ve çocuk için PYBÜ’ne kabul edilme diğer servislere kabul edilmeye oranla daha travmatik ve yaşamı tehdit edicidir. Çok ciddi hastalı̆̆ girişim yapılan hastaların taburculuktan 6 ay sonra çok daha fazla korktukları, duygularını kontrol etmekte zorlandıkları ve PTSB yaşadıkları bilinmektedir. ${ }^{1}$ Bununla birlikte PYBÜ'ne 
yatış çocuğun hayatında çok fazla karışıklığa neden olmakta, uzun süreli yatışlar okula devamı etkilemekte ve hastaneden çıktıktan sonra daha fazla kontrole gelmeyi gerektirmektedir. ${ }^{3}$

Çocuklarda PTSB için risk faktörleri açısından yaşları 6-16 arasında değişen 120 çocuk (60’1 PYBÜ’de, 60’1 genel servislerde yatan) ile yapılan prospektif kohort araştırmasında, taburculuk sonrası gruplar arasında psikolojik sonuçlar açısından bir fark olmadığ 1 , bununla birlikte ciddi hastalığ1 olan, küçük olan, invaziv girişimlerden çok fazla korkan, duygularını kontrol edemeyen çocukların taburculuktan 6 ay sonra PTSB semptomlarının arttığı bulunmuştur. ${ }^{18}$

Erişkin yoğun bakımda tedavi gören hastalarda, gece kabusları, hayal ve korkutucu halüsinasyon deneyimleri PTSB'nu başlatan birincil tetikleyicilerdir. ${ }^{1}$ Kaçınma travmanın sekeli olarak en fazla deneyimlenen ve ifade edilen duygudur. PYBÜ'de bulunan çocukların PTSB semptomlarından en çok kaçınma duygusunu yaşadıkları saptanmıştır. ${ }^{3}$ Muranjan ve $\operatorname{ark}^{19}$ (2007)'nın yaptığı çalışmada, PYBÜ'den taburcu olan iki çocukta kaçınma ve düşük öz saygı saptanmıştır. Yeni stresli olayların ve kaçınma semptomlarının önceki stresli olayları kronikleştirdiği ve PTSB'unun devam etmesine neden olduğu belirtilmektedir. ${ }^{20}$

Yoğun bakımdaki çocukların bilinç durumunda dalgalanmalar olmasına rağmen yoğun bakım ile ilgili neler hatırladıkları sorgulandığında; taburcu olan çocukların PYBÜ'nin genel görünümünü ve yaşadıkları deneyimleri hatırladıkları bilinmektedir. ${ }^{3}$ Playfor ve $\operatorname{ark}^{21}$ (2000)'nın PYBÜ'den taburcu olduktan 1 ve 28 gün sonra 38 çocuk ile yaptıkları araştırmada, çocukların \%57'sinin yoğun bakım ünitesini hatırladığını, \%15'inin yapılan birçok invaziv girişim nedeniyle yoğun bakıma karşı negatif duyguları olduğunu belirtmişlerdir. Karande ve $\operatorname{ark}^{2}$ (2005)'nın yaptığ 1 çalışmada ise, çocukların \%50'sinin yoğun bakımdan çıktıktan sonra en az bir kötü deneyimini unutmadığı, PYBÜ’de kalan çocukların \%24'ünün yoğun bakım hakkında negatif duygular hissettiği bulunmuştur.

Farklı birimlerde bulunan çocuklara göre PYBÜ'de bulunan çocuklar akut olarak daha sık hastalanmaktadır. PYBÜ'den taburcu olduktan sonra hastane ile yeniden ilişki kurma çocuğu iki şekilde etkiler. Bunlardan biri kaçınma semptomları, diğeri ise semptomların alevlenmesidir. Çocukta kaçınma semptomları varsa tedavi edilebilir ve hastane ortamında çocuğun hassasiyeti giderilebilir. İkinci olarak hastane ile yeniden ilişki içinde olmak PTSB semptomlarını arttırabilir, çocuk ve aileyi etkileyen semptomları yeniden tetikleyebilir., ${ }^{3,22}$ 
Tablo 1. Pediatrik yoğun bakım ünitesine yatış sonrası çocuklarda görülen post-travmatik stres bozukluğu

\begin{tabular}{|c|c|c|c|c|}
\hline $\begin{array}{c}\text { Araştırmacılar } \\
\text { (yıl) }\end{array}$ & Yaş & Katılan sayısı & $\begin{array}{c}\text { PTSB sıklığ } \\
(\%)\end{array}$ & Araştırma sonucu \\
\hline $\begin{array}{l}\text { Zink ve McCain } \\
(2003)^{10}\end{array}$ & $7-15$ & 143 & $\% 22$ & $\begin{array}{l}\text { Motorlu araç kazası sonrası görülen PTSB } \\
\text { ile yaş, cinsiyet, ırk ve yaralanma arasında } \\
\text { bir ilişkinin olmadığı bulunmuştur. }\end{array}$ \\
\hline $\begin{array}{l}\text { Bronner ve ark. } \\
(2008)^{15}\end{array}$ & $8<$ & 63 & $\% 13,8$ & $\begin{array}{l}\text { Katılan çocukların subklinik olarak } \\
\% 34,5 \text { 'inde PTSB semptomları görüldüğ̈̈ } \\
\text { ve PYBÜ'ne yatışı PTSB'nu tetiklediği } \\
\text { bildirilmektedir. }\end{array}$ \\
\hline $\begin{array}{l}\text { Judge ve ark. } \\
(2002)^{16}\end{array}$ & $2-15$ & 29 & $\% 10$ & $\begin{array}{l}\text { Kontrol grubu olmayan araştırmada bu } \\
\text { sonucun yoğun bakımda yatmış olmaktan } \\
\text { mı? ya da menengial sepsis ile ilişkili } \\
\text { olmasından mı? kaynaklandığı } \\
\text { bulunamamıştır. }\end{array}$ \\
\hline $\begin{array}{l}\text { Schreier ve ark. } \\
(\text { (2004) })^{17}\end{array}$ & $7-17$ & 83 & $\% 69$ & $\begin{array}{l}\text { Çocukların } \% 69 \text { 'unda hafif düzeyde PTSB } \\
\text { semptomları görülürken, } \% 57 \text { 'sinde bir ay, } \\
\% 59 \text { 'unda } 6 \text { ay ve } \% 38 \text { 'inde } 18 \text { ay sonra } \\
\text { semptomlar görülmüştür. }\end{array}$ \\
\hline $\begin{array}{l}\text { Rees ve ark. } \\
(2004)^{3}\end{array}$ & $5-18$ & $\begin{array}{c}68 \\
\text { 35- PYBÜ } \\
\text { 33- genel } \\
\text { çocuk servisi }\end{array}$ & $\begin{array}{l}\text { \%21-PYBÜ } \\
\text { Yok-genel } \\
\text { çocuk servisi }\end{array}$ & $\begin{array}{l}\text { Post travmatik stres bozukluğu PYBÜ’nde } \\
\% 21 \text { oranında görülürken, genel } \\
\text { servislerde yatan hiçbir çocukta } \\
\text { görülmemiştir. }\end{array}$ \\
\hline $\begin{array}{l}\text { Rennick ve ark. } \\
(2002)^{18}\end{array}$ & $6-16$ & $\begin{array}{c}120 \\
\text { 60- PYBÜ, } \\
\text { 60- genel } \\
\text { çocuk servisi }\end{array}$ & & $\begin{array}{l}\text { Gruplar arasında bir fark olmadığı, fakat } \\
\text { ciddi hastalığı olan, küçük olan, invaziv } \\
\text { girişimlerden çok fazla korkan, } \\
\text { duygularını kontrol edemeyen çocukların } \\
\text { taburculuktan } 6 \text { ay sonra PTSB } \\
\text { semptomlarının arttığı bulunmuştur. }\end{array}$ \\
\hline
\end{tabular}

\section{Pediatrik Yoğun Bakım Ünitesinde Çocuğu Bulunan Ailelerin Durumu}

Çocuğun PYBÜ'de bulunması aile için oldukça zordur. Aileler çocuklarının ölebileceğinden ya da sakat kalabileceğinden korkarlar. ${ }^{23}$ PYBÜ'de çocuğu yatmış olan ailelerde uykusuzluk, çocuğun yoğun bakımda olduğunu hatırlatan anıların olması, yoğun kızgınlık duyguları hissetme, hastane ile ilişkili olaylardan kaçınma gibi durumlar diğer ünitelerde yatan ailelere göre daha fazla ve daha yoğun bir şekilde deneyimlenmektedir. ${ }^{3}$ Ebeveynlerin hastanede yeni ve değişik ortamda bulunmaları ve çocuklarının ağrılı invaziv işlemlerine tanıklık etmeleri, tıbbi tedavi ve bakım hakkında karar vermek zorunda olmaları, istemeyerek de olsa çocuklarının hastalıkları ya da yaralanmalarını araştırmaları PTSB gelişimi açısından risk faktörlerini oluşturmaktadır. ${ }^{24}$ 
Araştırmalar ailelerdeki PTSB'nun yaklaşık olarak \%18-48 olduğunu belirtmişlerdir. ${ }^{25,26}$ Bronner ve ark. $^{22}$ (2008a )'nın yaptığı araştırmaya katılan 144 aileden, annelerin \%15'inde, babaların \%9.3'ünde PTSB tanımlanmıştır. PYBÜ'de çocuğu bulunan ailelerin dörtte birinin (\%27) diğer ünitelerde çocuğu bulunan ailelere oranla PTSB için daha fazla risk altında oldukları bulunmuştur. ${ }^{3}$

Çocuğu PYBÜ’de yatmış olan 272 aile ile yapılan araştırmada; her 15 aileden birinde PTSB semptomları bulunmuştur. Bu ailelerden 10 tanesi aşırı uyarılma davranışı göstermiş, dörtte üçü hastalık semptomlarını yeniden hatırladıklarını ifade etmiş ve üçte ikisi kaçış davranışı sergilemiştir. ${ }^{25} 50$ ailenin katıldığı başka bir çalışmada ventilasyon tedavisi gören çocukların ailelerinin diğer ailelere oranla daha fazla posttravmatik stres belirtileri gösterdikleri bulunmuştur. ${ }^{23}$ Çocuğu bypass ameliyatı geçiren 134 anne ve 98 babanın katıldığı başka bir çalışmada, katılan annelerin \%16,4'ünde babaların \%13,3'ünde hastaneden taburcu olduktan sonra PTSB görüldüğ̈̈ bulunmuştur. Kalp ameliyatından 6 ay sonra annelerin \%14,9'unda, babaların \%9,5'inde PTSB semptomları görülmüştür (Tablo 2). ${ }^{27}$

Çocuk ve ailenin PTSB semptomları arasında pozitif ilişki çocuk ve ailenin psikopatolojisi arasındaki etkileşimi ortaya koyabilir. Örneğin; aileler çocukları gibi benzer şekilde etkilenmişlerse, çocuklarının kaçınma duyguları ile baş etmesine yardım etmeleri zor gelebilir. Bu şekilde hem çocuk hem ailenin desteğe ihtiyacı olabilir.

\section{Post Travmatik Stres Bozukluğunun Azaltılmasında Hemşirenin Rolü}

Yoğun bakım üniteleri psikolojik, fizyolojik ve sosyal düzeyde yoğun stres yaşanmasına ve yoğun bakımdan taburcu olduktan sonra PTSB'nun gelişmesine neden olabilmektedir. Bu nedenle PYBÜ'ne kabul edilen çocuk ve ailesinin üniteye kabul edildikleri ilk andan itibaren PTSB'nu önlemek için uygulanacak hemşirelik bakımı, çocuk ve ailenin olası travma yaratıcı girişimlerden korumasını, bilgilendirilmesini ve taburculuğa kadar güvenli hasta bakımının sağlanması gibi önlemleri içermelidir.

Yoğun bakıma yatışı yapılan çocukların elde edilen bulgular doğrultusunda uygun hemşirelik tanıları konur. Yoğun bakım hastalarının hemşirelik bakımına yönelik geliştirilen rehberlerde PTSB'na neden olabilecek sık karşılaşılan sorunlara ilişkin aşağıdaki hemşirelik tanıları ele alınabilir. ${ }^{28,29}$

Tablo 2. Çocuğu yoğun bakım ünitesinde yatmış olan ailelerde görülen post-travmatik stres bozukluğu 


\begin{tabular}{|c|c|c|c|}
\hline $\begin{array}{c}\text { Araştırmacılar } \\
\text { (yıl) }\end{array}$ & Katılan sayısı & $\begin{array}{l}\text { PTSB sıklı̆̆ı } \\
\quad(\%)\end{array}$ & Araştırma sonucu \\
\hline $\begin{array}{l}\text { Bronner ve ark. } \\
(2008)^{22}\end{array}$ & 144 & $\begin{array}{l}\text { Anne: } \% 15 \\
\text { Baba: } \% 9,3\end{array}$ & $\begin{array}{l}\text { Akut olarak PYBÜ'ne yatışı yapılan çocukların } \\
\text { ailelerinde PTSB daha fazla görülmüştür. }\end{array}$ \\
\hline $\begin{array}{l}\text { Rees ve ark. } \\
(2004)^{3}\end{array}$ & $\begin{array}{c}68 \\
35 \text { PYBÜ } \\
33 \text { genel } \\
\text { çocuk servisi }\end{array}$ & $\begin{array}{l}\text { \%27-PYBÜ } \\
\text { \%7-genel çocuk } \\
\text { servisi }\end{array}$ & $\begin{array}{l}\text { Post travmatik stres bozukluğu PYBÜ’nde çocuğu } \\
\text { bulunan ailelerin \%27'sinde görülürken, genel } \\
\text { servislerde yatan ailelerin \%7'sinde görülmüştür. }\end{array}$ \\
\hline $\begin{array}{l}\text { Ballufi ve ark. } \\
(2004)^{25}\end{array}$ & 272 & $\begin{array}{l}\text { \%32- Akut stres } \\
\text { bozukluğu } \\
\text { 21- PTSB }\end{array}$ & $\begin{array}{l}\text { Ailelerin \%21'inde PTSB semptomları görüldüğ̈̈; } \\
\text { ayrıca akut olarak çocuklarının PYBÜ'ne yatışının } \\
\text { yapılması, çocuklarının öleceğinden korkmaları, } \\
\text { başka bir hastane transfer gibi durumlardan } \\
\text { korktukları ve yoğun bakımdan çıtıktan çok uzun } \\
\text { zaman sonra PTSB semptomları yaşadıkları } \\
\text { bulunmuştur. }\end{array}$ \\
\hline $\begin{array}{l}\text { Colville ve ark. } \\
(2009)^{23}\end{array}$ & 50 & $\% 88$ & $\begin{array}{l}\text { Çocuğu ventilasyon tedavisi gören ve yaşı büyük } \\
\text { olan ailelerin PTSB'na daha eğilimli olduğu } \\
\text { bildirilmiştir. }\end{array}$ \\
\hline $\begin{array}{l}\text { Helfricht ve ark. } \\
(2008)^{27}\end{array}$ & $\begin{array}{l}134 \text { anne } \\
98 \text { baba }\end{array}$ & $\begin{array}{l}\% 16,4 \text {-anne } \\
\% 13,3 \text {-baba }\end{array}$ & $\begin{array}{l}\text { Çocuğu bypass ameliyatı geçiren annelerin } \\
\% 16,4 \text { 'ünde babaların } \% 13,3 \text { 'ünde; taburcu olduktan } \\
6 \text { ay sonra annelerin \%14,9'unda, babaların } \\
\% 9,5 \text { 'inde PTSB semptomları görülmüştür. }\end{array}$ \\
\hline
\end{tabular}

- Yoğun bakımda uygulanan invaziv girişimler, yara bakımı ve hastalık ile ilişkili ağrı,

- Yapılan girişimler, 1şık, gürültü, aşırı uyaran ile ilişkili uyku örüntüsünde bozulma,

- Uyku bölünmesi ve yoğun bakımdaki aşırı uyaranlarla ilişkili konfüzyon riski,

- Ağrı, uzun süre hareketsizlik ile ilişkili fiziksel harekette bozulma,

- Vücutta oluşan değişiklikler ile ilişkili beden imajında bozulma,

- Bilgi eksikliği ile ilişkili korku ve anksiyete,

Yoğun bakımda uygulanan invaziv girişimler, yara bakımı ve hastalık ile ilişkili ağrı: Çocuğun ağrısı, sözel ağrı puanı ölçeği, veya davranışsal ve fizyolojik parametreleri içeren ağrı ölçekleri kullanılarak değerlendirilir. Çocukta ağrıya neden olabilecek işlemler (entübasyon, aspirasyon, damar yolu girişimleri, pozisyonlar vb) tanılanır ve uygulanacak girişimler öncesi çocuğun konforunun sağlanması amacıyla hekimin önerdiği analjezik ilaçlar uygulanır. Çocuğun günlük olarak ağrı ve sedasyon değerlendirmesi yapılarak gereksinim doğrultusunda hekimin önerdiği ilaçlar uygulanır. Yapılan girişimler sırasında farmakolojik tedavi ile birlikte uygun non-farmakolojik (masaj, dikkatin başka yöne çekilmesi, oyun vb.) ağrı geçirme yöntemleri kullanılır. ${ }^{28,29,30}$ 
Yapılan girişimler, ışık, gürültü, aşırı uyaran ile ilişkili uyku örüntüsünde bozulma: Gece çocuğa yapılacak olan girişimlerin mümkün olduğunca aynı saate toplanması ve çocuğun uyumasına fırsat verilmesi sağlanır. Çocuğun solunumunu rahatlamak için yapılan postural drenaj, öksürme egzersizleri aspirasyon gibi uygulamalar çocuk uyumadan önce gerçekleştirilerek rahat uyuması sağlanır. Mümkün ise yoğun bakım ünitesi çocuk ve ailesinin birlikte kalabileceği şekilde düzenlenir. Ortamdaki gürültü ve 1şık azaltılarak çocuğun uyku örüntüsünü sürdürmesi sağlanır. Yoğun bakımda tüm ünitenin aydınlatılması yerine hasta baş1 aydınlatma kullanılır. Monitör alarmları kısılır ve alarm limitleri hastaya özel olacak şekilde ayarlanır. Özellikle pozisyon yastıkları kullanılarak çocuğun konforlu uyuması sağlanmalıdır. ${ }^{28-31}$

Uyku bölünmesi ve yoğun bakımdaki aşırı uyaranlarla ilişkili konfüzyon riski: Çocuğun konforunun sağlanması için rahat ettiği pozisyonda tutulması, ağrılı işlemler öncesi gerekli girişimlerin yapılması, günlük sedasyon düzeyinin değerlendirilmesi önemlidir. Çocuğa uygulanan sedatifler azaltılarak kesilmeli ve yoksunluk belirtileri izlenmelidir. Ailenin yoğun bakım ünitesinde bulunması için uygun şartlar aratılmalı ve çocuğun bakımına ailenin katılımı sağlanmalıdır. Çocuğun uyku-uyanıklık durumu düzenlenerek bakımları planlanmalıdır. Yoğun bakımın gürültülü ve karışık ortamı çocuğa göre düzenlenerek, sevdiği eşyaları odasına getirebilmesine izin verilmeli ve mümkün olduğunca ev ortamı sağlanmaya çalışılmalıdır. $^{28,31}$

A ̆grı ve uzun süre hareketsizlik ile ilişkili fiziksel harekette bozulma: Çocuğun uzun süre aynı pozisyonda yatması ve oturması önlenerek, 2 saat aralıklarla pozisyonu değiştirilir. Pozisyonu değiştirilirken çocuğun onayı alınmalı ve mümkün olduğunca katılımı sağlanmalıdır. Gün içerisinde çocuk ve ailesinin birlikte vakit geçirmesi ve bu sırada ebeveynlerin çocuğu fiziksel harekete teşvik etmesi sağlanır. Ayak tabanı düşmesini önlemek için uygun tabanlıklarla ayaklar desteklenir. El düşmesini önlemek için uygun aparatlarla eller desteklenir. Uzun süre hareketsiz kalma ve kasların kullanılamamasına bağlı oluşabilen atrofinin önlenmesi için yatak içi aktif-pasif egzersizler yaptırılır ve ailenin katılımı sağlanır. Uygun esans yağlar kullanılarak çocuğa masaj yapılır ve rahatlaması sağlanır. Tolere ettikçe yatak dışında geçirilen zaman arttırılarak desteksiz yürümesi sağlanır. Düzenli bir egzersiz programı için fizyoterapist desteği sağlanır. ${ }^{30,31}$

Vücutta oluşan değişiklikler ile ilişkili beden imajında bozulma: Trakeostomi, gastrostomi, kolostomi gibi beden imajını değiştiren araçları olan ya da travma nedeniyle uzuv kaybı yaşayan çocuklar duygularını, özellikle kendisi hakkındaki düşündüklerini kendi bakış açısını ifade etmeleri için cesaretlendirilir. Beden imajında değişiklik ile ilgili ailenin 
duygularını ifade etmesi için firsat verilir. Mümkün ise aynı sorunları yaşamış yaşıtları ile tanıştırılması ve paylaşımda bulunulması sağlanır. ${ }^{28,29,31}$

Bilgi eksikliği ile ilişkili korku ve anksiyete: Çocuk ve ailesine yoğun bakıma giriş yapıldığı andan itibaren yoğun bakım ünitesi, yapılan işlemler, kullanılan araç-gereç ve hastalık ile ilgili anlayabilecekleri şekilde bilgi verilerek yoğun bakıma uyum sağlamaları için destek verilir. Yaşadıkları korkuları ifade etmeleri için cesaretlendirilir. Çocuğun sevdikleri ile birlikte daha fazla zaman geçirebilmesi sağlanır. Yoğun bakımına giriş ile başlatılan taburculuk planı çocuğun yoğun bakımdan taburculuğu ile sonlandırılır. Çocuk ve ailesine evde bakım konusunda bilgi verilir ve evde yaşanabilecek sorunlar için ulaşabileceği iletişim bilgileri verilir. Aileye PTSB nedenleri ve belirtileri ile ilgili bilgi verilir. Ailenin sosyal destekleri arttırılır. PTSB gelişimi açısından risk altında olan çocuk ve ailesi, gerekli ise taburculuk sonrası psikiyatrist ile görüşmeleri için teşvik edilir. Çocuk yoğun bakımdan taburcu edildikten sonra evdeki durumunun takip edilmesi için evde bakım ekibine teslim edilir. $^{31}$

Çocuk ve ailenin PYBÜ'de bulunması ile ilişkili olarak PTSB riskini araştıran deneysel çalışma sayısı oldukça yetersizdir. $\mathrm{Bu}$ alanda özellikle PYBÜ’de çalışan hemşirelerin araştırma yapması PTSB'nun azaltılması için bir adım olabilir. Multidisipliner ekip ile gerçekleştirilen bir çalışmada PTSB semptomlarının erken tanınması için geliştirilen rehber doğrultusunda değerlendirilen 26 hastanın \%96'sında Akut Stres Bozukluğu (ASB) saptandığı 1 ay sonra katılanların \%92'sinde PTSB ile ilişkili semptomlar tespit edildiği bildirilmiştir. $\mathrm{Bu}$ araştırma ile PTSB semptomlarının erken tanınmasının önemi vurgulanmıştır. $^{32}$

Peditrik yoğun bakım ünitesinde genel olarak aile merkezli bakım uygulanarak, çocukailenin birlikteliği ve ailenin sosyal destekleri artırılmalıdır. Ailenin kendini ifade etmesine ve soru sormasına fırsat verilmelidir. Gerekli ise aynı deneyime sahip diğer aileler ile tanıştırılarak endişe giderilmeye çalışılmalıdır. ${ }^{31}$

Sonuç olarak, PYBÜ'de bulunmak hem aile hem de çocuk için oldukça stres verici bir durumdur. Sağlık çalışanlarının, yoğun bakım ortamının çocuk ve aile üzerindeki etkilerini bilerek bakım uygulamalarını bu doğrultuda gerçekleştirmelerinin, taburculuk sonrası görülebilecek PTSB'nu azaltmada etkili olacağı düşünülmektedir. Taburculuk sonrası ev ziyaretlerinin yapılması ile yoğun bakım ortamından kaynaklanabilecek olumsuz duyguların azaltılması sağlanabilir ve böylece hasta/yakınlarının eve yeniden uyumu kolaylaşabilir. Ülkemizde evde bakım hizmetleri geliştirilerek yoğun bakımdan çıkan hasta ve hasta yakınlarının eğitimli personel tarafından desteklenmesi sağlanmalıdır. 


\section{Kaynaklar}

1. Begnoche WW. Posttraumatic stres symptoms in the pediatric intensive care unit. JSPN 2007;12(2): 84-92.

2. Karande S, Kelkar A, Kulkarni M. Recollections of Indian children after discharge from an intensive care unit. Pediatr Crit Care Med 2005;6:303-07.

3. Rees G, Gledhill J, Garralda ME, Nadel S. Psychiatric outcome following paediatric intensive care unit (PICU) admission: a cohort study. Intensive Care Med 2004;30:160714.

4. Vidyasagar D. Stress of admission to pediatric intensive care unit on children. Pediatr Crit Care Med 2005;6:374-76.

5. Şuer T. Posttravmatik stres bozukluğu. İ. Ü. Cerrahpaşa Tıp Fakültesi Sürekli Tıp Eğitimi Etkinlikleri, Medikal Açıdan Stres ve Çareleri. Sempozyum Dizisi 2005;47:205-10.

6. Mulvihill D. Nursing care of children after a traumatic incident. Issues in Comprehensive Pediatric Nursing 2007;30:15-28.

7. Kessler RC, Berglund P, Delmer O, Jin R, Merikangas KR, \& Walters EE. Lifetime prevalence and age-of-onset distributions of DSM-IV disorders in the National Comorbidity Survey Replication. Archives of General Psychiatry 2005;62(6):593-602.

8. Kessler R, Avenevoli S, Costello EJ, Georgiades K, Green JG, Gruber MJ. et al. Prevalence, persistence, and sociodemographic correlates of DSM-IV disorders in the National Comorbidity Survey Replication Adolescent Sample. Archives of General Psychiatry 2012;69:372-80.

9. Cuthbertson BH, Hull A, Strachan M, Scott J. Posttraumatic stress disorder after critical illness requiring general intensive care. Journal of Intensive Care Medicine 2004;30(3):450-55.

10. Zink KA, McCain GA. Post-Traumatic stress disorder in children and adolescents with motor vehicle related injuries. JSPN 2003;8(3):99-106.

11. Oflaz F. Hasta çocuk ve ebeveynlerinin pediatrik yoğun bakım deneyimi ve travmatik stres. C.U. Hemşirelik Yüksekokulu Dergisi 2008;12(1):53-59.

12. Granja C, Gomes E, Amaro A, Ribeiro O, Jones C, Carneiro A, Costa-Pereira A. Understanding posttraumatic stres disorder-related symptoms after critical care: The early ilness amnesia hypothesis. Crit Care Med 2008;36(10):2801-809.

13. Baker C. Preventing ICU syndrome in children. Paediatric Nursing 2004;16(10):32-35. 
14. Griffiths J, Fortune G, Barber V, Young JD. The Prevalence of post traumatic stres disorder in survivors of ICU treatment: a systematic review. Intensive Care Med 2007;33:1506-518.

15. Bronner MB, Knoester H, Bos AP, Last BF, Grootenhuis MA. Posttraumatic stress disorder (PTSD) in children after paediatric intensive care treatment compared to children who survived a major fire disaster. Child and Adolescent Psychiatry and Mental Health $2008 b ; 2: 1-9$.

16. Judge D, Nadel S, Vergnaud S, Garralda ME. Psychiatric adjustment following meningooccal disease treated on a PICU. Intensive Care Med 2002;28:648-50.

17. Schreier H, Ladakakos C, Morabito D, Chapman L, Knudson M. Posttraumatic stres symptoms in children after mild to moderate pediatric trauma: A longitudinal examination of symptom prevalence, correlates and parent-child symprom reporting. The Journal of Trauma Injury, Infection and Critical Care 2005;58(2):353-63.

18. Rennick JE, Johnson CC, Dougherty G. Children's psychological responses after critical illness and exposure to invasive technology. J Dew Behaw Pediatr 2002;23:133-44.

19. Muranjan MN, Birajdar SB, Shah HR, Sundaraman P, Tullu MS. Psychological Consequences in Pediatric Intensive Care Unit Survivors: The Neglected Outcome. Indıan Pediatrics 2007;45(17):99-103.

20. Perkonigg A, Pfister H, Stein MB, Hofler M, Lieb R, Maercker A, Wittchen HU. Longitudinal course of posttraumatic stress disorder and posttraumatic stress disorder symptoms in a community sample of adolescents and young adults. Am J Psychiatry 2005;162(7):1320-327.

21. Playfor S, Thomas D, Choonara I. Recollection of children following intensive care. Arch Dis Child 2007;83:445-48.

22. Bronner MB, Knoester H, Bos AP, Last BF, Grootenhuis MA. Follow-up after pediatric intensive care treatment: parental posttraumatic stres. Acta Paediatrica 2008a; 97:181-86.

23. Colville G, Cream P. Post-traumatic growth in parents after a child's admission to intensive care: maybe Nietzsche was right?. Intensive Care Med 2009;35:919-23.

24. Bal Yılmaz H, Ersun A. Hasta çocuk ve ebeveynlerinde post-travmatik stres bozukluğu. Ege Üniversitesi Hemşirelik Yüksek Okulu Dergisi 2010;26(3):45-50.

25. Balluffi A, Kassam-Adams N, Kazak A, Tucker M, Dominguez T, Helfaer M. Traumatic stres in parents of children admitted to the pediatric intensive care unit. Pediatr Crit Care Med 2004;5(6): 547-53. 
26. Shears D, Nadel S, Gledhill J, Garralda ME. Short-term psychiatric adjustment of children and their parents following meningococcal disease. Pediatr Crit Care Med 2005;6:39-43.

27. Helfricht S, Latal B, Fischer JE, Tomaske M, Landolt MA. Surgery related posttraumatic stres disorder in parents of children undergoing cardiopulmonary bypass surgery. A prospective cohort study. Pediatr Crit Care Med 2008;9(2):217-23.

28. Terzi B, Kaya N. Yoğun bakım hastasında hemşirelik bakımı. Dahili ve Cerrahi Bilimler Yoğun Bakım Dergisi 2011;1:21-5.

29. Erdemir F. [Nursing Diagnosis Hand Book]. 7. Baskı. İstanbul: Nobel Tıp Kitapevleri; 2005.

30. Birol L. [Nursing Process]. 9. Bask1, İzmir: Etki Matbaacılık; 2009.

31. Sönmez Düzkaya D, Bozkurt G. Yoğun bakım hastasının evde bakımı. Yoğun Bakım Hemşireliği Dergisi 2012;16(1):21-8.

32. Mclntosh S, Mata M. Early detection of posttraumatic stres disorder in children. Journal of Trauma Nursing 2008;13(3):126-30. 